\title{
Disadvantaged Individuals: Stigma as a Source of Entrepreneurial Motivation to Thrive
}

\author{
RABIA NASEER \\ PhD Scholar, Lecturer, Department of Management Sciences, Islamia College, Pakistan. \\ Email: rabia.naseer@icp.edu.pk \\ SHAHID JAN KAKAKHEL \\ Associate Professor, Department of Management Sciences, Islamia College, Pakistan. \\ Email: shahidjan@icp.edu.pk
}

FAYAZ ALI SHAH

Assistant Professor, Department of Management Sciences, Islamia College, Pakistan. Email: fayaz@icp.edu.pk

\begin{abstract}
Stigma is almost overlooked in the understanding entrepreneurial venture of disadvantaged individuals to create a venture. However numerous studies associated disadvantage as a foundation to initiate a venture. We study a new sample as a disadvantaged group who has been pushed to live at the margin of society on account of their non-binary gender identity. Based on an inductive study of fifteen trans-entrepreneurs, our model indicates stigma as a source of entrepreneurial motivation. It activates a sense of resilience either to gain respect and economic need (personal benefit) or to change the perception of society around stigma (prosocial) which enables them to thrive by creating a venture. The findings of this study open new horizons for further theoretical development and empirical research. This study also presents a self-help mechanism to disadvantaged individuals that enable them to overcome stigma.
\end{abstract}

Keywords: Entrepreneurial Motivation, Gender-based Stigmatization, Displacement or/and Disadvantage.

\section{Introduction}

The entrepreneurial motivation has a substantial impact on venture creation and ultimately on the global economy (Murnieks, Klotz, \& Shepherd, 2020). Besides considering numerous positive factors, research has now started focusing on negative factors as displacement or/and disadvantages as a source to create an entrepreneurial venture (Miller \& Le Breton-Miller, 2017). Previous theories demonstrated negative displacement (Shapero \& Sokol, 1982) and push factors (Gilad \& Levine, 1986) as a motivation to step into entrepreneurship. A recent study demonstrated these displacement/push factors as disadvantages (Miller \& Le Breton-Miller, 2017). These theories mainly focused on negative factors which overlooked to understand the underlying mechanism of entrepreneurial motivation to create a venture (Bernard \& Barbosa, 2016). To understand this, we explore that stigma associated to these disadvantages drives individuals to create an entrepreneurial venture with a purpose to change the perception of society about "an attribute that is deeply discrediting" (Goffman, 1963, p. 3). Despite evidencing stigma as a source of entrepreneurial motivation (e.g. Bacq et al., 2018), researchers overlooked to study it further. Researching stigma in the discipline of entrepreneurship is found to be mainly associated with the entrepreneurial failure (e.g. Simmons, Wiklund, \& Levie, 2014; Shepherd \& Haynie, 2011) whereas how stigma works for disadvantaged individuals to take an entrepreneurial initiative is limited. 
Stigmatization is a process in which an individual or group is considered as deviant based on their particular characteristics that evoke negative emotions and thoughts (Link, 2001). Those characteristics are translated as a mark of disgrace, called stigma. A stigmatized individual considered to have a known, apparent and discredited status (Miller \& Grollman, 2015). In this paper, we synonymy use stigmatized individuals as disadvantaged ones because the disadvantage of an individual makes them vulnerable to stigma. For instance, unemployment (Dougherty, Rick, \& Moore, 2017; Staiger et al., 2018), health-related issues and psychological disorder (Chan, Lee, \& Mak, 2018; Crowe, Averett, \& Glass, 2016; Stangl et al., 2019), disability (Bogart, Rosa, \& Slepian, 2019), and immigration (Nevin et al., 2018; Von Lersner, 2019). In addition to this, women were considered disadvantaged based on their gender that restricts them to access entrepreneurial resources (Fischer, Reuber, \& Dyke, 1993; Marlow \& Patton, 2005). The stigma associated with such disadvantages narrows the social identity of individuals (Chen, 2016) which restrict them to access life opportunities (Schaupp \& Bélanger, 2019).

Recognizing the call to contextualize the disadvantaged group with a change sample (Wiklund, Wright, \& Zahra, 2019), other than cisgender (Marlow \& Martinez Dy, 2018; Marlow, Hicks, \& Treanor, 2019); we contextualized this study in Pakistan, considering trans-entrepreneurs as a disadvantaged group in society. Their non-binary gender identity serves as a disadvantage for them based on which they are stigmatized and pushed to live at the margin of society. Transgender is an umbrella term which covers different gender deviances e.g. hermaphrodites (intersexed), transvestites (cross-dressers), a transgender man and transgender woman (Jami, 2005). Transgender man and woman are normally associated with gender dysphoria. It is characterized by "a conflict between a person's physical or assigned gender and the gender with which he/she/they identify" (American Psychiatric Association, 2020). Due to their non-binary gender identity, they are unable to access the groups or networks that can address their problems and enable them to learn the required skills to set up their entrepreneurial venture.

To explore the entrepreneurial motivation of disadvantaged individuals, we accessed and study transentrepreneurs who initiated their business being stigmatized in the social stream in large. In doing so, we make three contributions to the literature.

First, entrepreneurship is predominated with gender binary (Marlow \& Martinez Dy, 2018). To explore the entrepreneurial motivation of transgender individuals we are broadening the scope of gender in researching entrepreneurship. This effort will also assist the research community to view trans-entrepreneurs as one of the groups of disadvantaged entrepreneurs. They demand particular considerations in terms of their unique characteristics and socio-cultural dynamics that might determine the way they start and grow their business. Second, several studies highlighted push factors that influence disadvantaged individuals to opt for entrepreneurship (Shapero \& Sokol, 1982; Giland \& Levine, 1986; Miller \& Le Breton-Miller, 2017). We add a novel insight that stigma associated with disadvantage (displacement/push factor) as a source of entrepreneurial motivation to create a venture. Further, our study provides novel insights that stigma induces a sense of resilience that enable them to thrive and initiate a venture. The findings of our study may also benefit disadvantaged individuals to understand and adopt different strategies as a self-help guide to overcome stigma and change the perception of society about them by stepping into entrepreneurship.

Third, previous theories stated that disadvantaged individuals are motivated extrinsically to pursue entrepreneurship (e.g. Krueger, 1993; Kureger, Reilly \& Carsrud, 2000; Gilad \& Levine, 1986; Shapero \& Sokol, 1982). Recent research on entrepreneurial motivation has found that such individuals often motivated intrinsically (Shinnar \& Zamantılı Nayır, 2019) or by the integration of intrinsic and extrinsic motivation (Caliendo \& Kritikos, 2019; Levi \& Mezrar, 2019). To date, however, contradictory results have been found concerning the entrepreneurial motives of disadvantaged individuals. The findings of our results strengthen the consistent results. However, none of the disadvantaged individual found to be motivated extrinsically. 
To understand the entrepreneurial motivation of disadvantaged individuals, we address the following question: How do transgender individuals create an entrepreneurial venture being stigmatized in society? The empirical evidence in responding to this question will open new avenues for theoretical development in researching the entrepreneurial motivation of non-binary gender as disadvantaged individuals and stigmatization in general. By employing the inductive approach, we present a model that helps scholars to understand how stigmatization can be a source of entrepreneurial motivation to create a venture.

\section{Methods}

We employed inductive analysis to explore how stigma influence transgender individuals to create a venture? Initially, 18 transgender individuals were identified. We contacted them all via phone and after pre-screening, 15 were finally selected for an interview. The deselection of 3 cases was based on the reason that they did not create that venture, however working as a team member. We used pseudonyms to protect the identities of participants. Table 1 provides the details of the sample that we interviewed.

Table 1. Sample details

\begin{tabular}{|c|c|c|}
\hline Name & Industry & Description \\
\hline Chambeli & $\begin{array}{l}\text { Personal } \\
\text { Services }\end{array}$ & $\begin{array}{l}\text { A beauty salon dedicated to providing personal care services to } \\
\text { transgender individuals and the cisgender community. }\end{array}$ \\
\hline Heera & $\begin{array}{l}\text { Community } \\
\text { Development }\end{array}$ & $\begin{array}{l}\text { A social organization dedicated to working for the equality and civil } \\
\text { rights of transgender individuals. }\end{array}$ \\
\hline Kanwal & Clothing & $\begin{array}{l}\text { A venture provides tailored-made clothing for men in eastern and } \\
\text { western designs. }\end{array}$ \\
\hline Marjaan & Handicrafts & $\begin{array}{l}\text { A venture promotes hand made products i.e., dolls, ethnic jewellery } \\
\text { and decorative vases to promote traditions and culture. }\end{array}$ \\
\hline Meera & $\begin{array}{l}\text { Community } \\
\text { Development }\end{array}$ & $\begin{array}{l}\text { A social venture dedicated to advocate the rights, educate and } \\
\text { empower the transgender community. }\end{array}$ \\
\hline Mehak & Theatre & $\begin{array}{l}\text { A social venture devoted to engaging, inspiring and creating } \\
\text { awareness among audience about the lives of transgender individual } \\
\text { and deliver social messages theatrical productions that raise voice for } \\
\text { their right }\end{array}$ \\
\hline Mona & Fashion & $\begin{array}{l}\text { A fashion-based business committed to making apparels that to } \\
\text { discourage body shaming and encourage people of different ages to } \\
\text { carry different styles. }\end{array}$ \\
\hline Rani & Trading & $\begin{array}{l}\text { A trading business that sells electronic and furniture goods at } \\
\text { instalments. }\end{array}$ \\
\hline Sameera & $\begin{array}{l}\text { Food } \\
\text { Provider }\end{array}$ & $\begin{array}{l}\text { A Cafeteria provides exciting flavours in a traditional way to connect } \\
\text { people with traditions. }\end{array}$ \\
\hline Sangeeta & Clothing & $\begin{array}{l}\text { A clothing business provides custom to order made tailoring services } \\
\text { at reasonable prices. }\end{array}$ \\
\hline Sapna & $\begin{array}{l}\text { Community } \\
\text { Development }\end{array}$ & $\begin{array}{l}\text { A social venture dedicated to advocating the gender equality and } \\
\text { rights of transgender individuals. }\end{array}$ \\
\hline Sehar & $\begin{array}{l}\text { Personal Care } \\
\text { Services }\end{array}$ & $\begin{array}{l}\text { A beauty salon offers personal care services to women at reasonable } \\
\text { prices }\end{array}$ \\
\hline Shabnam & Fashion & A fashion-based venture offers ethnic dresses to women. \\
\hline Sonam & $\begin{array}{l}\text { Retail } \\
\text { Delivery }\end{array}$ & A venture provides home-made food at the customers' doorstep. \\
\hline Tani & $\begin{array}{l}\text { Community } \\
\text { Development }\end{array}$ & $\begin{array}{l}\text { A social venture promotes the rights of transgender individuals and } \\
\text { educates the community concerning health to improve their well- } \\
\text { being. }\end{array}$ \\
\hline
\end{tabular}


The selected transgender entrepreneurs have a different form of organization (profit, non-profit and hybrid) and they vary in size (between $2-21$ employees). The criteria of sample selection rested on our research question: a) all the selected individuals have created venture, and b) the founder of each case is transgender individual.

We employed an inductive research design to collect and analyze data (Gioia et al., 2013; Miles \& Huberman, 1994). In this study, 15 in-depth interviews were carried out (in total time duration of $15 \mathrm{~h}$ and 28 min which resulted in 317 pages of transcripts). We analyzed the data first and subsequently, discussed its interpretations with each member of our research team. Fig 1 demonstrates the process of data coding and analysis.

- Feeling uneasy about gender identity

- Questioning to self about difference in one's behaviour that family scolds at and friends and society mock

- Search about the one's identity, reading material, asking questions, observe the gender with similar behaviour and consequently, own it strongly.

- Scolding behaviour of family, mocking and bullying at school and outside

- Deprived of respect and love

- Verbal, physical and sexual abuse

- Isolation and depression

- Loss of family (abandoning)/ loss of job

- Pushed to abject way of earning

- Question to self-worth, social status and one's capabilities

- Realization of need for respect and social position in

- Society expect less from transgender individuals

- Reject to serve as a customer

- Loss of job due to transphobia

- Thought provoking motivation from family and friends

- Realization of the need for social change

- Self-awareness

- Set goals with a strong determination to achieve Motives translated into goals (personal benefit or prosocial)

- Sense entrepreneurial opportunity based on prior knowledge, and skills Linked with goals/motives to achieve

- Strategies to access entrepreneurial resources

- Backing with available support network

- Self-motivation to cope challenges

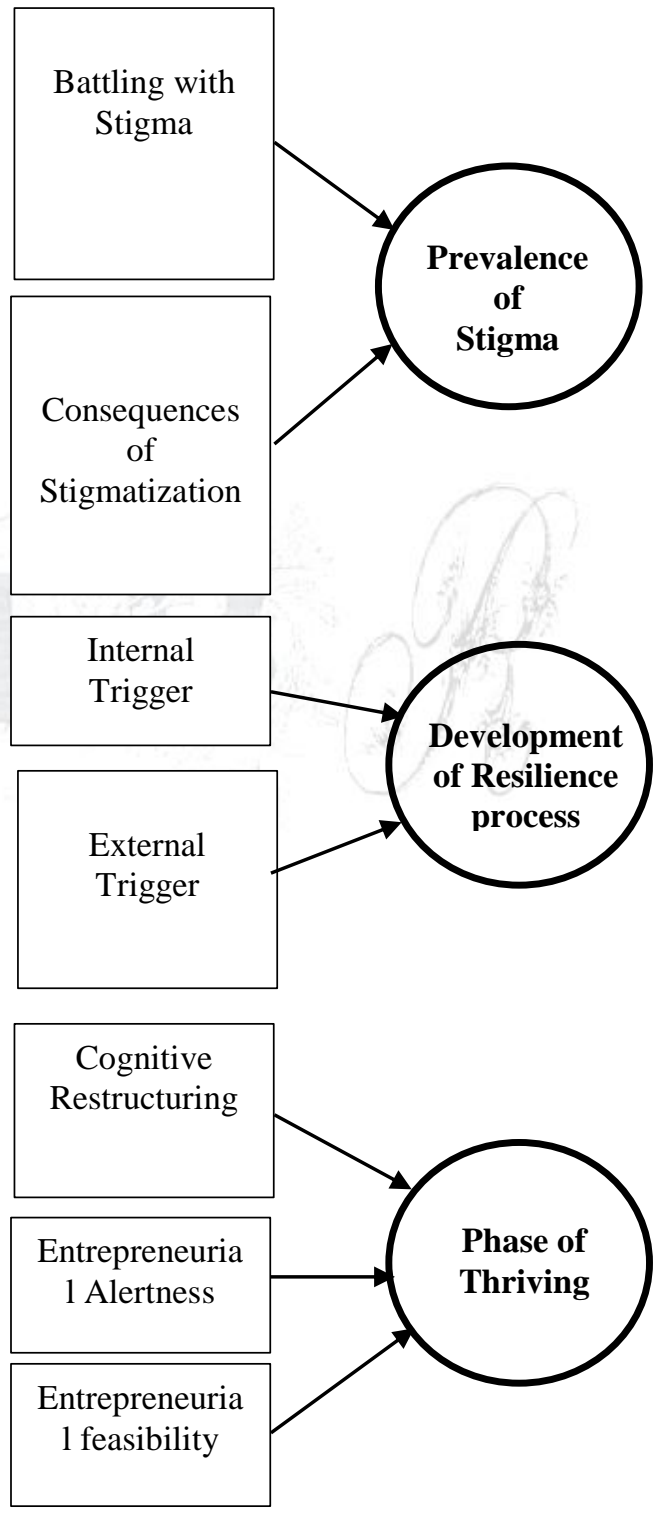

Fig 1. Data Structure diagram: process of coding and analysis 


\section{Result}

As presented in the model, there are three dimensions of entrepreneurial motivation that emerged from the experiences of transgender individuals. For the presentation of findings, we provided three displays: a) figure 2, demonstrated the emergent model, b) table 2 provided numerous illustrative quotations of participants, and c) progressing data structure diagram so that reader can get the insights of the data and findings.

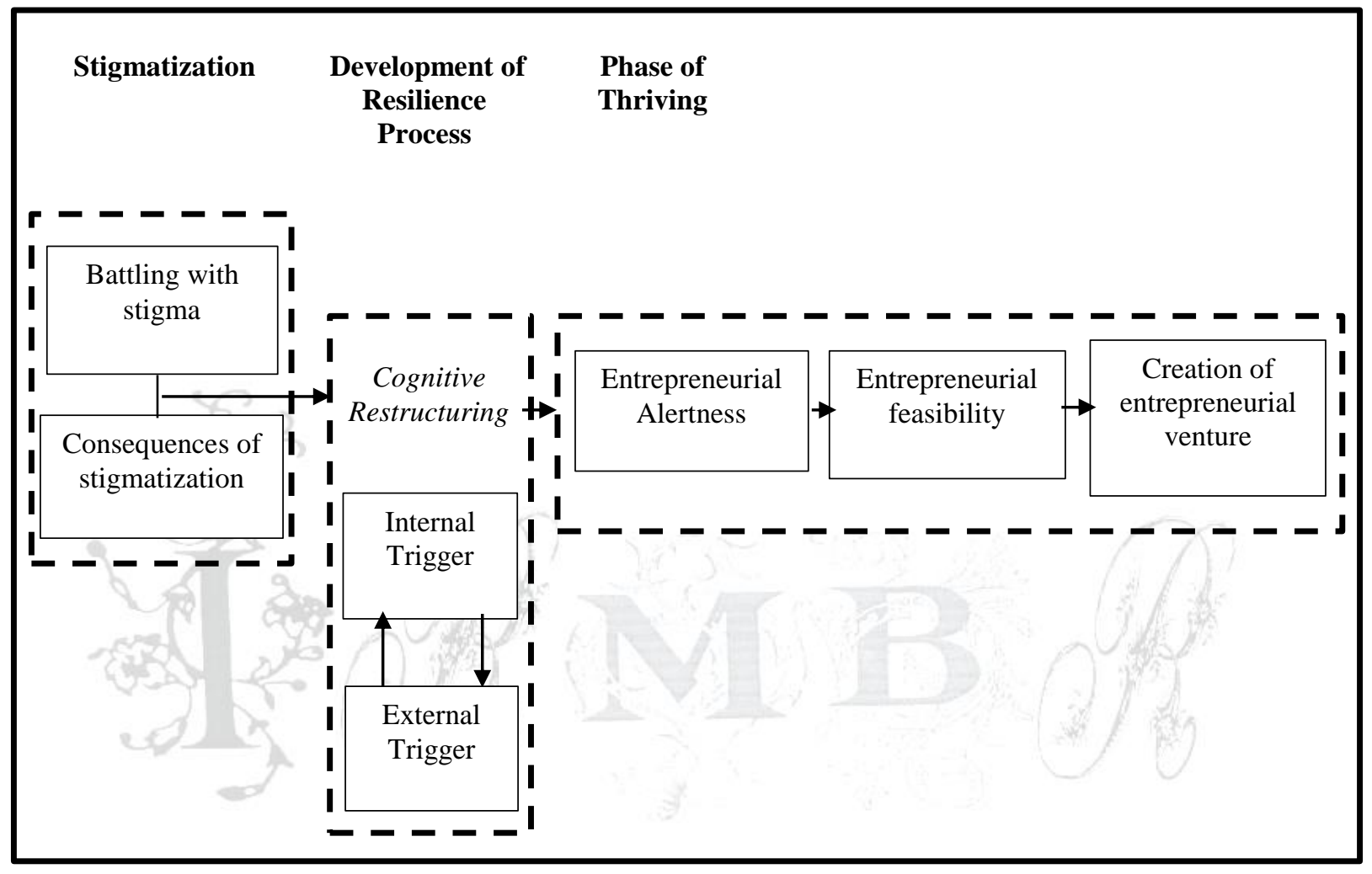

Fig 2. Stigma as a source of entrepreneurial venture to thrive

\section{Prevalence of Stigma}

Society is predominated with gender binary (i.e. woman and man). Their gender identity is different from the gender binary norms which makes them different to move in the society. In response to a question related to "how do you experience your social interaction in society?" most answers revolved around mocking, discrimination, negative stereotyping, physical and sexual abuse. Aspects of the prevalence of stigma included such experiences as "I used to listen to comments like, go way, you hijra (a slang word to name a transgender individual). I did not know about this term but later I got to know that it is a transidentity that people used to make fun of this identity by using such words" (Sapna), "My family used to judge me on my feminine behaviour and strike me with a negative attitude. My siblings tried to fix me, they believed that over time I will be normal but overtime when they did not notice any change, they started to scold me" (Meera). At my school, I faced sarcasm equally from boys and girls, who used to stereotypical transgender clap as I passed by", "This place is not for people like us because no one accepts and loves us. People used to mock at me by passing comments like, hey look khusra is going there, go, go away, you khusra and you khusra" (Rani). 
Participants were quite sure about the prevalence of stigma in society. Our findings revealed two insights, first, in their early age they were unaware of the reason of stigmatization that why people mock at them, why they have been scolded on the way they act. Such unawareness about their gender identity made them battle with the stigma. We found it as an evolutionary process of understanding one's gender identity, accepting and taking it as a strength to become a different person. Second, in every situation, they have been dehumanized and discredited based on their non-binary gender identity. We depicted this process as stigmatization which resulted in numerous consequences that led their lives

\section{Battling with Stigma}

Almost all participants experienced an unnerving and distressing childhood where they find themselves battling with the stigma associated with their gender identity. Getting repression from family and society make them a question about their gender identity, what's different about them? What's wrong in their behaviour? Why everyone bore into them? And why their family members scold them on the way they talk and act? These questions make them disturbing to know about their identity. As one transgender individual put it, "I used to feel different from others. There is a soul of a woman in a man. People feel that I am a man, acting like a woman, but I am a woman inside" (Marjaan). Such feelings push them to know more about their gender identity. In the search of their identity, they exert so much effort like one transgender individual shared, "to learn about uneasy feelings about my gender identity, I studied tons of articles, browsed different websites, explored documentaries, paid visits to a psychiatrist to understand my identity" (Mehak). It was the case with almost all participants, they explored their gender identity and acceptance marvellously. It was noteworthy when one transgender individual expressed the level of acceptance and owning her gender identity by wishing that, "If I get rebirth in this world, so I want to become a transwoman again in a way that I'm today" (Chambeli). The understanding and acceptance of their gender identity could not prevent them from the stigma but in another way, it supported them to own themselves.

\section{Consequences of Stigma}

The one who is labelled with a particular stigma such as non-binary gender in this study, the consequences are inevitable. The theme emerged at the indication of numerous consequences that participants confronted in their lives on account of their different gender identity.

As one transgender individual shared, "When I worked as a beautician at a beauty salon, I used to greet every client but they never bother to reply me. Mostly clients refused to get a service from me. Why? Just because I am a trans-woman" (Chambeli). The similar pattern of rejection based on their gender identity has observed across cases however at different levels. For a few, the stigmatization is restricted them to access job opportunities and pushed them to the abject way of earning. To illustrate, one transgender individual indicated, "I wanted to do a respectable job, but whenever I visited any organization for an interview, they refused to hire me. Massive rejection and hatred pushed me to beg on the streets" (Sameera).

Lack of job opportunities for the transgender community makes them hard to survive, but what if they get a job? Will they be able to survive in an organization dominated with gender binary? A clear example of such a situation is indicated by one of the transgender individuals when reporting her experience of working in an organization, "The organization where I worked for five years, terminated me based on transphobia" (Meera).

The consistent stigma resulted in rejection to accept them as a person. The deleterious attitude of their biological family and society makes them feel redundant and worthless. Such feelings make them isolated socially. One transgender individual put it this way, "Massive rejection from society made me take drugs. I used to not come out from my apartment for weeks" (Mehak). 
Table 2: Data supporting the interpretation of the mechanism of stigma as entrepreneurial motivation

\begin{tabular}{|c|c|}
\hline Themes & Representative Quotations \\
\hline & Stigmatization \\
\hline $\begin{array}{l}\text { Battling with gender } \\
\text { identity }\end{array}$ & $\begin{array}{l}\text { "In my early life, I used to feel uneasy about my gender. Makeup and girly stuff } \\
\text { fascinated me. I wanted to look beautiful like girls" (Sehar) } \\
\text { "In search of my identity, I joined the community. I used to ask a question from } \\
\text { the community members that why people disrespect us. } \\
\text { "I used to feel different from others. There is a soul of a woman in a man. } \\
\text { People feel that I am a man and act like a woman but I am a woman inside" } \\
\text { (Marjaan) }\end{array}$ \\
\hline $\begin{array}{l}\text { Consequences of } \\
\text { stigmatization }\end{array}$ & $\begin{array}{l}\text { "When I worked as a beautician at a beauty salon, I used to greet every client but } \\
\text { they never bother to reply to me. Mostly clients refused to get a service from me. } \\
\text { Why? Just because I am a trans-woman" (Chambeli). } \\
\text { "I wanted to do a respectable job, but whenever I visited any organization for an } \\
\text { interview, they refused to hire. Massive rejection and hatred pushed me to beg } \\
\text { on the streets" (Sameera) } \\
\text { "During my growing age, my parents started scolding, beating and punishing me } \\
\text { when they observed any deviance in my behaviour. The consistent repressive } \\
\text { behaviour of my family pushed me to abandon my home" (Tani) } \\
\text { "Massive rejection from society made me take drugs. I used to not come out } \\
\text { from my apartment for weeks" (Mehak) }\end{array}$ \\
\hline & The development process of resilience \\
\hline External trigger & $\begin{array}{l}\text { "My relatives used to criticize me that he is a transgender individual and he } \\
\text { cannot do anything. Their statements hit me deep inside and made me think if } \\
\text { they can do so why not I?" (Sonam) } \\
\text { "Despite knowing my passion and hard work at work, the organization } \\
\text { terminated me based on transphobia. I was the time when I started thinking } \\
\text { about myself, what should I do? Am I not capable enough to be accepted at any } \\
\text { workplace?" (Meera) } \\
\text { "I contacted all the top-notch beauty salons, but they rejected to serve me based } \\
\text { on my gender identity" (Chambeli). } \\
\text { "One day, my father said to me, you are a transgender individual but you have a } \\
\text { brain, hands and feet. Do something big that I feel pride in you. Society will } \\
\text { never accept you until you do not change the way they think about you. It is in } \\
\text { your hands" (Heera) } \\
\text { "When I started meeting with community members, I realized that numerous } \\
\text { people are having much pain than me. They have no jobs, they are pushed to } \\
\text { begging and prostitution. People do not respect them as a human. I felt there is a } \\
\text { need for a social change that can only change the dynamics of the community" } \\
\text { (Mehak) }\end{array}$ \\
\hline Internal trigger & $\begin{array}{l}\text { "Stigmatization and negative stereotyping give me so much pain as it kills you } \\
\text { inside, not for once but countless time. To overcome this pain, I realized that I } \\
\text { need to work hard so that I can change the repressive attitude of society" } \\
\text { (Kanwal) } \\
\text { "Money can be earned in several ways, why can I not earn money respectfully? } \\
\text { Do not I have potential to do something? What should I do? The way people } \\
\text { look at me and make fun of me kills me inside" (Sangeeta) } \\
\text { "I joined the community where I followed the abject way of earning but, deep } \\
\text { inside something bugged me that why would I do this? Why would I not earn } \\
\text { money respectably?" (Shabnam) }\end{array}$ \\
\hline
\end{tabular}




\begin{tabular}{|c|c|}
\hline $\begin{array}{l}\text { Cognitive } \\
\text { restructuring }\end{array}$ & $\begin{array}{l}\text { "Consistent stigma pushed me in the isolation where I battled with myself to } \\
\text { overcome the rejection. I realized if I will not fight for my identity so no one } \\
\text { else does it for me." (Mehak) } \\
\text { My father's comment changed my mind that it is not only me who is a victim of } \\
\text { such stigmatization but the whole community. Afterwards, I started to think that } \\
\text { what should I do for the community? (Heera) } \\
\text { "I quit all the abject ways of earning because I didn't feel ok with that. It was a } \\
\text { time when I had lost any hope for life. It took my so much effort to recollect my } \\
\text { energies and the support of my friend helped me to think differently about life } \\
\text { and it worked" (Shabnum) } \\
\text { "The stigma attached to trans-identity kills us. Over time, I realized that we need } \\
\text { social change. If we could not bring it, then we can never change the repressive } \\
\text { attitude of society towards us" (Mehak). } \\
\text { "I used to be quiet and not say a word against their witty comments. I was } \\
\text { hopeless but my friend realized me my potentials that I can do something better. } \\
\text { I want that people accept me as a person" (Sonam) }\end{array}$ \\
\hline & Phase of Thriving \\
\hline $\begin{array}{l}\text { Entrepreneurial } \\
\text { feasibility }\end{array}$ & $\begin{array}{l}\text { "Being rejected as a customer by top-notch salons, I realized that there are no } \\
\text { such salons which serve transgender customers" (Chambeli) } \\
\text { "The massive stigmatization and hatred towards transgender individuals pushed } \\
\text { me to advocate the rights of the community" (Tani) } \\
\text { "I am good at communication. People used to call me to speak on transgender } \\
\text { issues. Later I realized that they are using me to demonstrate me as a showpiece } \\
\text { so that they can get funds from donors. I felt the need of our organization which } \\
\text { can work for our community (Heera) } \\
\text { "Since working in different organizations, I feel tremendous transphobia that } \\
\text { restricts our employment opportunities and career growth. I felt the need to have } \\
\text { an organization that works for the economic empowerment of transgender } \\
\text { community" (Meera) } \\
\text { "The sufferings of the community motivated me to work for a social change" } \\
\text { (Sapna) } \\
\text { "I convinced my community members to work for our rights because no one else } \\
\text { can do this for us. Our community members contributed financially to kick-start } \\
\text { it until we get fund from the donor. I believe transgender individuals are } \\
\text { emotionally strong than cisgender and they perform well as a team member" } \\
\text { (Heera) } \\
\text { "I am a business graduate and also have a diploma certificate in fashion } \\
\text { designing. My family know my skills so they granted me a loan of PKR } 6 \text {, } \\
\text { 00,000 to start a venture. It helped to manage other resources" (Mona) } \\
\text { "I am a certified beautician. My friend help me to access financial resource to } \\
\text { start a beauty salon though it was not easy" (Chambeli) } \\
\text { "What we need to start our organization, our rented room was our office and our } \\
\text { community members were our team members. What we earned from the abject } \\
\text { of earning, we invested in our organization. We worked together for ourselves to } \\
\text { get the fund from donors for our first project" (Tani) } \\
\text { "I used to save money from begging and purchase small pieces of cloth usually } \\
\text { "It was only my heart who wanted to prove myself and motivated me to access } \\
\text { the resources and overcome challenges on the way. I did not lose courage } \\
\text { because I know no one will push me for my goals. I need to do this for myself" } \\
\text { (Rani) }\end{array}$ \\
\hline
\end{tabular}




\begin{tabular}{|c|c|}
\hline $\begin{array}{l}\text { Creation of } \\
\text { entrepreneurial } \\
\text { venture }\end{array}$ & $\begin{array}{l}\text { "The idea of investing my capabilities, energy and time never comforted me } \\
\text { where I don't get respect. I decided to work for myself and support my } \\
\text { community. I know, I can do better than a cisgender because I am emotionally } \\
\text { stronger than them. I have capabilities based on which I accessed and created } \\
\text { resources so why should I chose to become a victim of stigma?" (Sapna). } \\
\text { "I believe that every individual should earn money respectfully. Begging on the } \\
\text { streets never comforted me but the consistent stigma and hatred realized my } \\
\text { strengths and capabilities to me that I am no less. I have the skill to make } \\
\text { handicraft products and I started the small venture that helps me to get } \\
\text { independence and improve my economic condition. I believe in this way people } \\
\text { will respect me too" (Marjaan). } \\
\text { "Being a transgender individual, I have been suffered a lot and I can understand } \\
\text { the sufferings of my community. They have no job opportunities; people do not } \\
\text { accept them as a human where I believe they have the potential to learn and } \\
\text { grow. So, I created an organization with a philosophy to empower the } \\
\text { transgender community by providing them training so that they can work for } \\
\text { themselves" (Mehak). }\end{array}$ \\
\hline
\end{tabular}

\section{The development process of Resilience}

The central theme that emerged from our data is the development of resilience that set the foundation of the transformation process. As every participant has gone through the experience of stigmatization resulted in the rejection, distress, and social isolation. These negative experiences develop a sense of resilience. The process of resilience represents the ability of an individual to bounce back to the negative experiences and recover oneself from negative consequences. Three specific themes emerged relating to the development process of resilience characterized the stigmatized experiences of our participant in two ways; external trigger and internal trigger which consequently arose another theme i.e. restructuring of cognitions.

\section{External Trigger}

Our findings revealed external trigger in two forms; first the natural trigger from the consequences of stigma in terms of loss of family, unavailability of job, transphobia at work, and realization for the social change. Second, when a member from the support network (family, friends or community) realized transgender individuals about the need for recognition and achievement concerning their particular skills.

"My relatives used to criticize me that he is a transgender individual and he cannot do anything. Their statements hit me deep inside and made me think if they can, do so why not I?" (Sonam). In terms of their gender identity, they compare themselves with cisgender which help them to determine who they are as a person? Are they not capable of doing something in life? They do not want to imply the societal perspective to define them or to try to change oneself as per the norms of society. They own their gender identity very strongly. As one transgender individual narrated, "I never feel different, but society makes me realize that I am different. It hurts, but I feel comfortable in my skin. I need to prove that I can do better than cisgender" (Sehar). But does ownership of their gender identity prevent them from massive stigmatization? Where society does not accept them as a person. As one transgender individual put it, "despite knowing my passion and hard work at work, organization terminated me based on transphobia." (Meera). Transgender individuals accepted the stigmatization but society does not give them any space for inclusion. As one example of such external trigger is illustrated by one transgender individual by sharing her experience of rejection, "I contacted all the top-notch beauty salons, but they rejected to serve me based on my gender identity" (Chambeli). Such a repressive attitude of society does not leave any space of inclusion for them. Then the question arises on the ability of transgender individuals how to cope with such a rejection? Whether they chose to become a victim? Or decide to redefine oneself that society accepts them? 
There are few cases where the external trigger was found in the form of realization of a social change. To illustrate, one transgender individual put in, "when I started meeting with community members, I realized that numerous people are having much pain than me. They have no jobs, they are pushed to begging and prostitution. People do not respect them as a human. I felt there is a need for a social change that can only change the dynamics of our community" (Mehak).

Besides looking external trigger in the forms of negative events, we observed few triggering events in terms of thought-provoking motivation from family and friends. As one transgender individual put in, "one day, my father said to me, you are a transgender individual but you have a brain, hands and feet. Do something big that I feel pride in you. Society will never accept you until you do not do something that changes the way they think about you. Your future is in your hand" (Heera).

Almost in every case, transgender individuals were triggered by some external negative events either in the form of negative events or a though-provoking motivation that made them question themselves about their self-worth as a person and capabilities. Society expects less from transgender individuals, they label their source of earning only to the abject ways e.g. begging on streets, singing and dancing on different occasions and prostitute themselves. But what if they want to do something different? Will society allow them to do so? Will they make themselves capable enough to prove themselves? Can they change the way society thinks about them? These are the questions of interest concerning this study that unfolded at every step as we move forward in the interview.

\section{Internal Trigger}

"Money can be earned in several ways, why can I not earn money respectfully? Do not I have potential to do something? What should I do? The way people look at me and make fun of me kills me inside" (Sangeeta). An internal trigger is the natural consequence of stigmatization where transgender individual feel deprived of respect and love. Based on this deprivation, they question themselves about their selfworth, social status and one's capabilities. This deprivation realizes them the need for respect and social position. As one transgender individual put in, "stigmatization gives me so much pain as it kills you inside, not for once but countless time. I realized that I need to work hard so that I could change the repressive attitude of society" (Kanwal). Our findings revealed that consistent stigmatization led them in distress and social isolation. During these times they push themselves hard to accept the realities and motivate themselves for living. To illustrate this, one transgender individual narrated, "During the time of isolation and distress, I seek help from ALLAH. I motivated myself to achieve my dream. I know no one pushes me for this, I need to do this for myself, for my respect and dignity" (Mona).

An internal and external trigger is related to each other. Their relationship depicts how the external triggering e.g. stigmatization and negative events drive internal trigger which makes them question themselves and realizes the need for respect where they mostly rely on self-motivation. This realization helped them to restructure their cognitions.

\section{Restructuring of Cognitions}

Based on the external and internal trigger, they restructure their cognitions. This process involves changing negative thoughts into a positive one. The main contributing factor in the restructuring of cognitions is selfmotivation and support network. It induced thought-provoking motivation that helped them to change their perspective towards life. They started analyzing their capabilities and setting life goals. To illustrate, one transgender put in, "My father's comment changed my mind that it is not only me who is a victim of such stigmatization but the whole community. Afterwards, I started thinking that what should I do for the community? (Heera) ). Another transgender individual narrated, "I used to be quiet and not say a word against their witty comments. I was hopeless but my friend realized me my potentials that I can do something better. I want that people accept me as a person" (Sonam). 
These triggers made them realize the need of change either in form of changing one's thoughts into the positive one so that they can achieve in life (personal motive) or the need to change the way people perceive about them (prosocial motive). As one transgender individual put in, "I quit all the abject ways of earning because I didn't feel ok with that. It was a time when I had lost any hope for life. It took my so much effort to recollect my energies and the support of my friend helped me to think differently about life and it worked. I needed to earn but respectfully" (Shabnum). Another transgender shared, "The stigma attached to trans-identity kills us. Over time, I realized that we need social change. If we could not bring it, then we can never change the repressive attitude of society towards us" (Mehak).

\section{Phase of Thriving}

The phase of thriving represents a process in which individuals learn from the negative experiences such as stigmatization and its consequences in this study. Based on this learning they decide to grow. Thus, the phase of thriving arose from the stigmatized experiences as they coped with negative experiences of stigmatization and learn how to redefine themselves based on the restructuring of cognitions that allow them to know their strengths and capabilities. Knowing one's strengths and capabilities support them to create a venture. Three specific themes relating to the phase of thriving characterized our participants' experiences: a) entrepreneurial alertness, b) entrepreneurial feasibility, and c) creation of the entrepreneurial venture.

\section{Entrepreneurial Alertness}

The alertness to entrepreneurship depicts the identification of an entrepreneurial need (opportunity) based on the prior knowledge and skills as entrepreneurial alertness. Almost in all cases, entrepreneurial alertness has noticed. As they restructured their cognitions that helped them to set their life goals in terms of gaining respect and bring a social change that benefits their community. These motives alert them to the need of entrepreneurial venture. For instance, one transgender individual put in, "being rejected as a customer by top-notch salons, I realized that there are no such salons which serve transgender customers" (Chambeli). Another transgender individual shared her experience of identifying entrepreneurial need based on prosocial motive, "since working in different organizations, I feel tremendous transphobia that restricts our employment opportunities and career growth. I felt the need to have an organization that works for the economic empowerment of transgender community" (Meera).

\section{Entrepreneurial Feasibility}

One cannot take an initiative until they do not find the entrepreneurial idea feasible in terms of availability of resources (team, financial, and physical resources). The prevalence of stigma restricts a transgender individual to access entrepreneurial resources. To access these resources, they strived hard and rely more on themselves while backing with a support network, they imply creative strategies. As one transgender individual put in, "what we needed to start our organization, our rented room was our office and our community members were our team members. The amount we earned from the abject ways, we invested in our organization. We worked together for ourselves to get the fund from donors for our first project" (Tani).

Cisgender distant them to have any social interaction so they rely more on their community members to develop a team. As one transgender individual shared her experience of accessing resources, "I convinced my community members to work for our rights because no one else can do this for us. Our community members contributed financially to kick-start it until we get fund from the donor. I believe transgender individuals are emotionally strong than cisgender and they perform well as a team member" (Heera). During the feasibility of the entrepreneurial venture, one might face a downturn where one finds it hard to continue. In such a situation, transgender individuals find their friends and community members highly supportive. As one transgender individual put in, "I am a certified beautician. My friend helped me to 
access financial resource to start a beauty salon though it was not easy. We both knew that I can do this" (Chambeli). Another transgender individual shared, "I am a business graduate and also have a diploma certificate in fashion designing. My family know my skills so they granted me a loan of PKR 6, 00,000 to start a venture. It helped to manage other resources" (Mona). It is noteworthy that the family which rejected to accept her initially, supported her later when she proved her skills and wanted to achieve something in life. Every intended entrepreneur needs an emotional and resourceful network that can help them to manage resources and overcome challenges. But what if they lack any support. Our findings revealed that in such cases they rely upon self-motivation. As one transgender individual put in, "it was only my heart who wanted to prove myself and motivated me to access resources and overcome challenges on the way. I did not lose courage because I know no one will push me for my goals. I need to do this for myself' (Rani).

\section{Creation of Entrepreneurial Venture}

Recognizing one's strengths and creating the accessibility of entrepreneurial resources allowed transgender individual deciding to create an entrepreneurial venture. Almost all transgender individuals believed that they are no less than cisgender and can do better than them. To illustrate, one transgender individual reported, "The idea of investing my capabilities, energy and time never comforted me where I don't get respect. I decided to work for myself and support my community. I know, I can do better than a cisgender because I am emotionally stronger than them. I have capabilities based on which I accessed and created resources so why should I chose to become a victim of stigma?" (Sapna).

The foundation of their entrepreneurial venture is based on the nature of motives which derive from stigmatization. Our findings revealed two types of motives: personal motive and prosocial motive. Some transgender individuals believed to work in a way so that they gain respect, and economic gain that indicated their motive. As one transgender individual explained, "I believe that every individual should earn money respectfully. Begging on the streets never comforted me but the consistent stigma and hatred realized my strengths and capabilities to me that I am no less. I have the skill to make handicraft products and I started the small venture that helps me to get independence and improve my economic condition. I believe in this way people will respect me too" (Marjaan). In some other cases, the prosocial motive has found that translated entrepreneurial venture of transgender individuals in bringing a social change that may transform the landscape of the transgender community in terms of economic and social empowerment. As one transgender individual put in, "Being transgender individual, I have been suffered a lot and I can understand the sufferings of my community. They have no job opportunities, people do not accept them as a human where I believe they have the potential to learn and grow. So I created an organization with a philosophy to empower the transgender community by providing them training so that they can work for themselves" (Mehak).

\section{Discussion}

Numerous academic papers have documented the challenges that transgender individual face and their consequences. However, very few papers have explored the entrepreneurial insights/dynamics of transgender entrepreneurs (Marlow and Martinez Dy, 2018; Marlow, Hicks, \& Treanor, 2019). The present study is the first step towards understanding how do transgender individuals motivate to create a venture being stigmatized in society?

The model we develop in this paper suggests that the resilience process that is built on the stigma, realizes the need for respect and economic gain. It translates into motives of disadvantaged individuals into two broad categories; personal motive and prosocial motive. These motives take individuals to the phase of thriving where they learn from negative experiences of stigmatization and step forward to grow. We interpret the process of resilience and phase of thriving as a transformational process of disadvantaged individuals which enable them to translate their motives into the creation of entrepreneurial venture and consequently transform them into a new a being as an entrepreneur. 
Our findings contribute to the extent of literature in three ways. First, we unfolded how the stigma induces a sense of resilience and enable individuals to thrive. Previous theories presented that displacement/push factors drive individuals to create a venture (e.g. Shapero \& Sokol, 1982; Giland \& Levine, 1986). However, we added a novel insight that that stigma associated with push factor which we considered as a disadvantage influences individuals to initiate a venture. This insight will open a new debate to understanding the push factors differently as a driver to start a venture.

Second, previous researches focused on the stigma of business failure and reentry of stigmatized individuals in the business (e.g. Simmons, Wiklund, \& Levie, 2014; Shepherd \& Haynie, 2011). By contrast, our work was undertaken to understand how gender-based stigma influence transgender individuals to create an entrepreneurial venture. We provided a novel insight that pervasive and consistent stigma transform an individual into an entrepreneur through the process of resilience and thriving that resulted in the creation of the venture. But in the pervasive and consistent stigma, would they be able to survive in the market? What motives can drive them to survive? What strategies would be beneficial for them to grow their business? These questions call future exploration to understand how stigmatized entrepreneurs manage their business.

Third, we explored that the stigma is the foundation of entrepreneurial motivation, however prior research, overwhelmingly emphasized that negative factors/displacements or disadvantages drive individuals to initiate a venture (Shapero \& Sokol, 1982; Giland \& Levine, 1986; Miller \& Le Breton-Miller, 2017). It is the stigma attached to these negative factors or disadvantage that drive the process. In contrast with entrepreneurship literature predicting that stigma influences negatively on the lives of individuals (Hughto, Reisner, \& Pachankis, 2015). We provide novel insights that how stigma drive individuals positively to transform them into an entrepreneur. But how becoming an entrepreneur influence their socio-cultural life? Would this transformational process influence society destigmatize them? These questions can be addressed further to understand the influence of entrepreneurship on their social acceptance.

Deci and Ryan (1995) made a distinction between intrinsic and extrinsic motives which is taken in entrepreneurial research as push and pull factors (Giland \& Levine, 1986; Shapero \& Sokol, 1982). Conventionally the push factors are associated with negative factors that influence an individual to step into entrepreneurship (Giland \& Levine, 1986; Shapero \& Sokol, 1982). However, recent research on entrepreneurial motivation has found that such individuals often motivated intrinsically (Shinnar \& Zamant1l1 Nayır, 2019) or with the integration of intrinsic and extrinsic motivation (Caliendo \& Kritikos, 2019; Levi \& Mezrar, 2019). The results are consistent with these studies. Our study revealed that stigma associated with disadvantage motivated individuals in two ways i.e. extrinsically or by the integration of intrinsic and extrinsic motivation. However, none of the individuals motivated extrinsically. We demonstrated the need for respect and economic gain as the integration of both intrinsic and extrinsic motives whereas we support the evidence of intrinsic motive in terms of prosocial motive. Murnieks, Klotz, and Shepherd (2020) indicated prosocial motives as an emerging area of interest in researching entrepreneurial motivation. Several researchers analyzed how prosocial motivates influence individuals to alleviate the suffering of other that translated into a venture (e.g. Miller et al., 2012; Patzelt \& Shepherd, 2011; Renko, 2013; Williams \& Shepherd, 2016). For further studies, stigmatized led social organizations can be explored to analyze their impact on society. Such studies will bring new insights that how these ventures shifting the mindset of people towards their respective communities.

We suggest three strategies as a self-help mechanism to disadvantaged individuals so that they can protect themselves from the stigma associated with their respective disadvantage and enable them to grow. First, they need to accept the prevalence of stigma and own their disadvantage based on which they are stigmatized so that they cannot influence negatively from the repressive attitude of society. Second, they need to identify their resilient mentor (family, friends, and community member) who can help them to restructure their cognitions from negative to the positive one. The positive approach towards life will 
enable them to define their goals and help them to grow. Third, they need to identify or develop a skill that can help them to uplift their livelihood.

\section{Conclusion}

Our study evident entrepreneurship as a way to gain respect and economic gain. In addition to this, we indicated that disadvantaged individuals stepped into entrepreneurship to bring a social change. Can every disadvantaged individual become an entrepreneur? No, but the one who accepts one's disadvantage such as a case of non-binary gender in this study; who accept and own their gender identity yet based on which they are stigmatized. They bounce back to stigma by realizing one's strengths and need for respect either individual or social level which translated into new motives that enable them to create a venture.

\section{Reference}

American Psychological Association. (2020). The road to resilience. Retrieved from https://www.apa.org/topics/resilience

Bacq, S., Toubiana, M., Ajunwa, I., Ormiston, J., \& Ruebottom, T. (2018). Stigma Entrepreneurship: Exploring Stigma As A Source Of Entrepreneurial Motivations. Frontiers of Entrepreneurship Research.

Bernard, M. J., \& Barbosa, S. D. (2016). Resilience and entrepreneurship: A dynamic and biographical approach to the entrepreneurial act. M@n@gement, 19(2), 89-123. DOI: 10.3917/mana.192.0089

Bogart, K. R., Rosa, N. M., \& Slepian, M. L. (2019). Born that way or became that way: Stigma toward congenital versus acquired disability. Group Processes \& Intergroup Relations, 22(4), 594-612.

Caliendo, M., \& Kritikos, A. S. (2019). "I want to, but I also need to": start-ups resulting from opportunity and necessity. In From Industrial Organization to Entrepreneurship (pp. 247-265). Springer, Cham.

Chan, K. K. S., Lee, C. W., \& Mak, W. W. (2018). Mindfulness model of stigma resistance among individuals with psychiatric disorders. Mindfulness, 9(5), 1433-1442.

Chen J., Courtwright A. (2016). Stigmatization. In: ten Have H. (eds). Encyclopedia of Global Bioethics. Springer, Cham

Crowe, A., Averett, P., \& Glass, J. S. (2016). Mental illness stigma, psychological resilience, and help seeking: What are the relationships?. Mental Health \& Prevention, 4(2), 63-68.

Deci, E. L., \& Ryan, R. M. (1995). Human autonomy. In Efficacy, agency, and self-esteem (pp. 31-49). Springer, Boston, MA.

Dougherty, D. S., Rick, J. M., \& Moore, P. (2017). Unemployment and social class stigmas. Journal of applied communication research, 45(5), 495-516.

Fischer, E. M., Reuber, A. R., \& Dyke, L. S. (1993). A theoretical overview and extension of research on sex, gender, and entrepreneurship. Journal of business venturing, 8(2), 151- 168. DOI: 10.1016/08839026(93)90017-Y

Gilad, B., \& Levine, P. (1986). A behavioural model of entrepreneurial supply. Journal of small business management, 24 (4), 45-53

Gioia, D. A., Corley, K. G., \& Hamilton, A. L. (2013). Seeking qualitative rigor in inductive research: Notes on the Gioia methodology. Organizational research methods, 16(1), 15-31.

Goffman, E. (1963). Stigma. Englewood Cliffs, NJ: Prentice-Hall.

Haynie, J. M., \& Shepherd, D. (2011). Toward a theory of discontinuous career transition: Investigating career transitions necessitated by traumatic life events. Journal of Applied Psychology, 96(3), 501.

Hughto, J. M. W., Reisner, S. L., \& Pachankis, J. E. (2015). Transgender stigma and health: A critical review of stigma determinants, mechanisms, and interventions. Social science \& medicine, 147, 222231.

Jami, H. (2011). Condition and status of hijras (transgender, transvestites etc.) in Pakistan: Country report.

Krueger Jr, N. F., Reilly, M. D., \& Carsrud, A. L. (2000). Competing models of entrepreneurial intentions. Journal of business venturing, 15(5-6), 411-432. DOI: 10.1016/S0883- 9026(98)00033-0 
Krueger, N. F., \& Carsrud, A. L. (1993). Entrepreneurial intentions: Applying the theory of planned behaviour. Entrepreneurship \& Regional Development, 5(4), 315-330. DOI: $10.1080 / 08985629300000020$

Levi, D., \& Mezrar, B. (2019). Factors motivating immigrants to establish a business-The case of Sweden.

Link, B. G., \& Phelan, J. C. (2001). Conceptualizing stigma. Annual review of Sociology, 27(1), 363-385.

Marlow S., Hicks S., Treanor L. (2019). Gendering Entrepreneurial Behaviour. In: McAdam M., Cunningham J. (eds) Entrepreneurial Behaviour. Switzerland: Palgrave Macmillan, Cham Marlow, S., \& Martinez Dy, A. (2018). Annual review article: Is it time to rethink the gender agenda in entrepreneurship research?. International Small Business Journal, 36(1), 3-22. DOI: 10.1177/0266242617738321

Marlow, S., \& Patton, D. (2005). All credit to men? Entrepreneurship, finance, and gender. Entrepreneurship theory and practice, 29(6), 717-735.

Miles, M. B., \& Huberman, A. M. (1994). Qualitative data analysis: An expanded sourcebook. Sage. Thousand Oaks, CA: Sage Publications.

Miller, D., \& Le Breton-Miller, I. (2017). Underdog entrepreneurs: A model of challenge-based entrepreneurship. Entrepreneurship Theory and Practice, 41(1), 7 -17. DOI: 10.1111/etap.12253

Miller, L. R., \& Grollman, E. A. (2015, September). The social costs of gender nonconformity for transgender adults: Implications for discrimination and health. In Sociological Forum (Vol. 30, No. 3, pp. 809-831).

Miller, T. L., Grimes, M. G., McMullen, J. S., \& Vogus, T. J. (2012). Venturing for others with heart and head: How compassion encourages social entrepreneurship. Academy of management review, 37(4), 616-640.

Murnieks, C. Y., Klotz, A. C., \& Shepherd, D. A. (2020). Entrepreneurial motivation: A review of the literature and an agenda for future research. Journal of Organizational Behavior, 41(2), 115-143. DOI: $10.1002 /$ job. 2374

Nevin, P. E., Frey, S., Lipira, L., Endeshaw, M., Niemann, L., Kerani, R. P., \& Rao, D. (2018). "You are always hiding. It's the worst way to live." Exploring Stigma in African Immigrants Living With HIV in a Large Northwest US Metropolitan Area. Journal of the Association of Nurses in AIDS Care, 29(3), 417-425.

Patzelt, H., \& Shepherd, D. A. (2011). Recognizing opportunities for sustainable development. Entrepreneurship Theory and Practice, 35(4), 631-652.

Renko, M. (2013). Early challenges of nascent social entrepreneurs. Entrepreneurship theory and practice, 37(5), 1045-1069.

Schaupp, L. C., \& Bélanger, F. (2019). Social commerce benefits for small businesses: An organizational level study. In Social Entrepreneurship: Concepts, Methodologies, Tools, and Applications (pp. 12371255). IGI Global.

Shapero, A., \& Sokol, L. (1982). The social dimensions of entrepreneurship. In C. A. Kent, D. L. Sexton, \& K. H. Vesper (Eds.), Encylclopedia of entrepreneurship (pp. 72-90). Englewood Cliffs, NJ: PrenticeHall.Shapero, A., \& Sokol, L. (1982). The social dimensions of entrepreneurship. Encyclopedia of entrepreneurship, 72-90.

Shepherd, D. A., \& Haynie, J. M. (2011). Venture failure, stigma, and impression management: A selfverification, self-determination view. Strategic Entrepreneurship Journal, 5(2), 178-197.

Shinnar, R. S., \& Zamantılı Nayır, D. (2019). Immigrant Entrepreneurship in an Emerging Economy: The Case of Turkey. Journal of Small Business Management, 57(2), 559-575.

Simmons, S. A., Wiklund, J., \& Levie, J. (2014). Stigma and business failure: implications for entrepreneurs' career choices. Small Business Economics, 42(3), 485-505.

Simmons, S. A., Wiklund, J., \& Levie, J. (2014). Stigma and business failure: implications for entrepreneurs' career choices. Small Business Economics, 42(3), 485-505.

Staiger, T., Waldmann, T., Oexle, N., Wigand, M., \& Rüsch, N. (2018). Intersections of discrimination due to unemployment and mental health problems: the role of double stigma for job-and help-seeking behaviors. Social psychiatry and psychiatric epidemiology, 53(10), 1091-1098. 
Stangl, A. L., Earnshaw, V. A., Logie, C. H., van Brakel, W., Simbayi, L. C., Barré, I., \& Dovidio, J. F. (2019). The Health Stigma and Discrimination Framework: a global, crosscutting framework to inform research, intervention development, and policy on health-related stigmas. BMC medicine, 17(1), 31.

Von Lersner, U., Gerb, J., Hizli, S., Waldhuber, D., Wallerand, A. F., Bajbouj, M., ... \& Hahn, E. (2019). Stigma of mental illness in Germans and Turkish immigrants in Germany: The effect of causal beliefs. Frontiers in psychiatry, 10, 46.

Wiklund, J., Wright, M., \& Zahra, S. A. (2019). Conquering Relevance: Entrepreneurship Research's Grand Challenge. Entrepreneurship: Theory and Practice, 43(3), 419-436. DOI: 10.1177/1042258718807478

Williams, T. A., \& Shepherd, D. A. (2016). Building resilience or providing sustenance: Different paths of emergent ventures in the aftermath of the Haiti earthquake. Academy of Management Journal, 59(6), 2069-2102. 